\title{
Cytotoxicity of $N$-dodecanoyl-L-homoserine lactone and 5- $N$-dodecyl resorcinol to human granulocytes and monocytes: a comparative study
}

\author{
TATYANA SVIRIDOVA ${ }^{1}$, DMITRY DERYABIN ${ }^{l}$, OLGA CYGANOK $^{1}$, VALERY CHERESHNEV \\ ${ }^{1}$ Orenburg State University, Russian Federation \\ ${ }^{2}$ Institute of Ecology and Genetics of Microorganisms at the Ural Branch of the Russian Academy of Sciences, Russian Federation
}

\begin{abstract}
Small molecules originating from microbes (SMOMs) play a significant role in bacterial-bacterial communication and in interactions between bacteria and their hosts. The aim of this study is a comparative analysis of the cytotoxic activity to human granulocytes and monocytes of two structurally close SMOMs: $\mathrm{N}$-dodecanoyl-L-homoserine lactone $\left(C_{12}-H S L\right)$ and 5-N-dodecyl resorcinol $\left(C_{12}-A R\right)$. Cell viability was determined by Trypan blue dye exclusion. To distinguish cell death mechanisms, both necrosis and apoptosis tests were carried out. Cells undergoing apoptosis were identified by caspase-3 activity and the level of histone-associated DNA fragments. To evaluate cell lysis, the lactate dehydrogenase release test was used. In addition, the SMOM's action on erythrocyte membrane stability was investigated.

The investigated SMOMs in micromolar concentrations showed more dose-dependent cytotoxicity against granulocytes than monocytes, but they used different mechanisms to impinge on the cell death pathway. $C_{12}$-HSL specifically induced apoptosis similar to the activity previously reported for 3-oxo$N$-dodecanoyl-L-homoserine lactone that originated from Pseudomonas aeruginosa. In contrast, $C_{12-}$ $A R$ induced fast cytolytic effects (necrosis) as shown by the release of cytoplasmic lactate dehydrogenase, and presumably were defined by cellular membrane destabilisation.

Our data demonstrate that both $C_{12}$-HSL and $C_{12}$-AR can eliminate key defence cells, which would otherwise participate in the destruction of pathogenic bacteria. These results reinforce the SMOMs bifunctionality concept that such bacterial molecules not only regulate bacterial-bacterial interactions but also break immune defences as a new and important mechanism of host evasion.
\end{abstract}

Key words: apoptosis, cytotoxicity, necrosis, $N$-dodecanoyl-L-homoserine lactone, 5-N-dodecyl resorcinol.

(Centr Eur J Immunol 2013; 38 (3): 310-316)

\section{Introduction}

Small molecules originating from microbes (SMOMs) play a significant role in bacterial-bacterial communication and also in inter-kingdom signalling: interactions between bacteria and their hosts [1]. Examples of SMOMs are $\mathrm{N}$-acyl homoserine lactones (HSLs) and resorcinolic lipids (RLs); they vary in the structure of the nonpolar $N$-acyl chain and polar lactone or resorcinol single-ring. The HSLs are involved in quorum sensing, which is a mechanism of bacterial gene expression control in response to increasing cell density [2]. The RLs are synthesised by some pro- and eukaryotes [3] and operate as inductors of bacterial cell transition into the dormant stage [4]. On the other hand, these amphiphilic substances diffuse easily through epithelial barriers into human liquids and tissues where experimentally detected HSLs and RLs concentrations vary from nano- to micro-molar [5, 6]. As a result, HSLs affect the function of a wide range of mammalian cell types (including cells of the immune system), repress the production of

Correspondence: Tatyana Sviridova, Orenburg State University, Pobedy av. 13, Office 16 306, 460018 Orenburg, Russian Federation, e-mail: kobtg@yandex.ru 
cytokines, disrupt the function of antigen-presenting cells [7, 8], and alter cell metabolism and cycling [9]. In turn, RLs could act in the human body as antioxidant, antigenotoxic, and cytostatic agents [10].

An extreme SMOMs biological activity is a cytotoxic effect potentially developing in two ways: necrosis and apoptosis. Mammalian cells undergoing necrosis typically lose membrane integrity, shut down metabolism and release their contents into the environment [11]. In contrast, apoptotic cells do not lyse but activate specific energy-dependent mechanisms that lead to condensation of chromatin and cleavage of DNA into regularly sized fragments [12]. Cytotoxic activities have been shown for different HSLs $[13,14]$ or RLs $[15,16]$ in some cases observed by the induction of apoptosis, and can be explained by their interactions with DNA and membrane-associated targets. However, the similarities or distinctions of these small molecules in cytotoxicity are not completely clear.

The aim of this study is a comparative analysis of the cytotoxic mechanisms of two structurally close HSL and RL: $N$-dodecanoyl-L-homoserine lactone and 5- $N$-dodecyl resorcinol in human granulocytes and monocytes.

\section{Material and methods}

\section{Chemicals}

$\mathrm{N}$-dodecanoyl-L-homoserine lactone $\left(\mathrm{C}_{12}\right.$-HSL) was purchased from Cayman Chemical Company (Michigan, USA). 5- $N$-dodecyl resorcinol $\left(\mathrm{C}_{12}\right.$-AR) was synthesised according to standard organic procedures and purified to $99 \%$ homogeneity by preparative liquid chromatography by Enamine Ltd. (Kiev, Ukraine). These compounds have a similar acyl chain but typical of HSLs and ARs polar head groups, respectively (Fig. 1).

$\mathrm{C}_{12}$-HSL and $\mathrm{C}_{12}$-AR stock solutions $(0.01 \mathrm{M})$ were prepared in $96 \%$ ethanol, and diluted in Hank's balanced salt solution (HBSS) or $0.85 \% \mathrm{NaCl}$ solution containing $5 \%$ ethanol immediately before use. The basic concentrations varied from $10^{-4} \mathrm{M}$ to $10^{-7} \mathrm{M}$, which corresponded to the experimentally-detected presence of HSLs and RLs in biological liquids and tissues of humans $[5,6]$.

\section{Cell culture and treatments}

Human granulocytes and monocytes were isolated from leukocyte-rich plasma originating from heparin-treated peripheral blood $<2 \mathrm{~h}$ old. The plasma samples were put on a double ficoll-verografine density gradient (1.077 and $1.092 \mathrm{~g} / \mathrm{ml})$, and were centrifuged at $800 \times \mathrm{g}$ for $15 \mathrm{~min}$ at $24 \pm 4^{\circ} \mathrm{C}$. The cells that had been separated on high (monocytes) and low (granulocytes) density barriers were gently washed with cold HBSS and resuspended in Medium 199 to concentrations of $1.05 \pm 0.12 \times 10^{6}$ for granulocytes and $1.73 \pm 0.15 \times 10^{6}$ for monocytes, which reflect the physiological leukocytes parities.
The $900 \mu$ granulocyte or monocyte suspensions were plated in wells containing $100 \mu \mathrm{C}_{12}$-HSL and $\mathrm{C}_{12}$-AR dilutions or an equal HBSS volume (control); they were then incubated in a humidified atmosphere containing $5 \% \mathrm{CO}_{2}$ at $37 \pm 1^{\circ} \mathrm{C}$. After 1 to $4 \mathrm{~h}$ of incubation, the probes were centrifuged at $1,000 \times \mathrm{g}$ for $5 \mathrm{~min}$, and cells or supernatants were tested in different cytotoxicity assays.

For hypotonic stress experiments, cells originating from heparin-treated peripheral blood erythrocytes were washed three times with a $0.85 \% \mathrm{NaCl}$ solution, resuspended to 108 cells $/ \mathrm{ml}$, and pre-incubated with $\mathrm{C}_{12}$-HSL and $\mathrm{C}_{12}$-AR dilutions at $37^{\circ} \mathrm{C}$ for $1 \mathrm{~h}$.

\section{Cytotoxicity assays}

Cell viability test by Trypan blue dye exclusion: The cells treated with or without $\mathrm{C}_{12}$-HSL and $\mathrm{C}_{12}$-AR were collected at the indicated time point and were mixed $1: 1$ with 0.001 M Trypan blue (TB) solution in PBS. The cell colouring and counting were examined by light microscopy in a hemocytometer. The percentage of $\mathrm{TB}(+)$ dead cells stained blue due to vital dye was calculated by comparison to that of non-treated control granulocyte and monocyte suspensions.

Quantitation of apoptosis markers: To evaluate the induction of apoptosis, caspase- 3 activity and the level of histone-associated DNA fragments were determined in cells treated with $\mathrm{C}_{12}$-HSL and $\mathrm{C}_{12}$-AR.

The quantitative presence of active caspase- 3 was measured using the Quantikine ELISA kit (R\&D Systems, Minneapolis, USA). After centrifuge preparations, cells were lysed by denaturing extraction buffer containing biotinylated caspase inhibitor diluted 10-20 fold with a calibrator diluent. Caspase- 3 activity in cell extracts was determined using a caspase-specific monoclonal antibody coated on the microplate and horseradish peroxidase conjugated to streptavidin that binds to the biotin on the caspase-attached
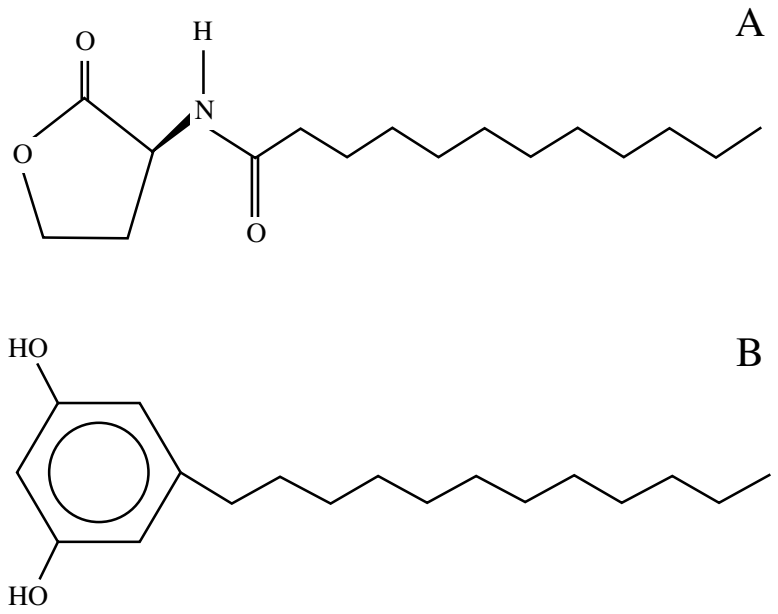

Fig. 1. Structures of $\mathrm{C}_{12}$-HSL (A) and $\mathrm{C}_{12}-\mathrm{AR}$ (B) used in this study 
inhibitor. Calculations were compared to a standard curve and presented as the caspase- 3 concentration (ng/ml) of each sample multiplied by the diluting factor.

DNA fragmentation and nuclear membrane breakdown in the $\mathrm{C}_{12}$-HSL and $\mathrm{C}_{12}$-AR treated cells were quantified by the measurement of cytoplasmic mono- and oligonucleosome DNA fragments using the Cell Death Detection ELISA kit (Roche Diagnostics, Mannheim, Germany) according to the manufacturer's instructions. Fixed on the microplate wall, mouse monoclonal antibodies specific to the H1-H4 histones and conjugated with horseradish peroxidase anti-DNA antibodies, were used in this sandwichenzyme-immunoassay. Specific enrichment of mono- and oligonucleosomes released into the cytoplasm was calculated using the following formula: enrichment factor (EF) $=\mathrm{A}_{405}$ treated cells $/ \mathrm{A}_{405}$ control cells.

Cells lysis assays: To evaluate cell membrane integrity, the lactate dehydrogenase (LDH) release test was used. The colorimetric measurement of LDH activity in $\mathrm{C}_{12}$-HSLand $\mathrm{C}_{12}$-AR-treated granulocyte and monocyte supernatants was performed using the LDH-UV-Novo kit (Vector-Best, Novosibirsk, Russia) according to the manufacturer's instructions. The reduction of pyruvate to lactate in the presence of NADH was monitored kinetically at $340 \mathrm{~nm}$ by the rate of decrease in absorbance $(\Delta)$, and enzyme activity (EA) was calculated as $\Delta / \min \times 6.592$.

In a separate experiment, the action of $\mathrm{C}_{12}$ - $\mathrm{HSL}$ and $\mathrm{C}_{12^{-}}$ $\mathrm{AR}$ on erythrocyte membrane stability was investigated [17]. The 50- $\mu \mathrm{l}$ aliquots of treated and control samples were added to tubes containing $5 \mathrm{ml}$ of $0.40-0.85 \% \mathrm{NaCl}$ solutions, gently mixed, and incubated at $37^{\circ} \mathrm{C}$ for $30 \mathrm{~min}$ before being centrifuged at $1500 \times \mathrm{g}$ for $15 \mathrm{~min}$. Erythrocyte lysis was followed by measuring the absorbance of the supernatants at $540 \mathrm{~nm}\left(\mathrm{~A}_{540}\right)$ and was presented as percentage of haemolysis depending on $\mathrm{NaCl}$ content. In turn, these data were used for the calculation of integral membrane stability parameters, which was evaluated by the half-transition point $\left(\mathrm{X}_{50}\right)$ obtained from the curves of haemoglobin efflux induced by the increase in medium hypotonicity.

\section{Statistical analysis}

Data are reported as \pm standard errors of the mean of determinations performed in triplicate on three different samples and were analysed by the Student's $t$-test. A $P$ value of less than 0.05 was considered significant. Calculations were performed with Statistica V8 for Windows (Stat Soft Inc., Tulsa, USA).

\section{Results}

\section{Loss of granulocyte and monocyte viability caused by $\mathrm{C}_{12}$-HSL and $\mathrm{C}_{12}$-AR}

$\mathrm{C}_{12}$-HSL and $\mathrm{C}_{12}$-AR had similar effects evaluated by the cell viability assay, such as the uptake of a dye (Trypan blue) by dead cells after breakdown of the cellular permeability barrier. The cytotoxicity of both compounds was concentration-dependent with varying effects depending on the cell type used (Table 1).

The counting of stained granulocytes demonstrated about $1.4 \pm 0.8 \%$ of $\mathrm{TB}(+)$ cells in control samples. However, in $\mathrm{C}_{12}$-HSL $\left(10^{-6}, 10^{-5}, 10^{-4} \mathrm{M}\right)$ treated samples, the percentage of $\mathrm{TB}(+)$ cells increased gradually to 34.0 $\pm 1.84 \%, 92.1 \pm 4.88 \%$, and $96.1 \pm 4.99 \%$, respectively $(p \leq 0.01) . \mathrm{C}_{12}$-AR cytotoxicity was detected at concentrations of $10^{-5}$ and $10^{-4} \mathrm{M}$ with $68.6 \pm 3.49 \%$ and 95.9 $\pm 4.98 \%$ of $\mathrm{TB}(+)$ cells, respectively $(p \leq 0.001)$. The lowest $\mathrm{C}_{12}$-HSL and $\mathrm{C}_{12}$-AR concentrations did not induce cytotoxicity.

The toxicity of $\mathrm{C}_{12}$-HSL and $\mathrm{C}_{12}$-AR to monocytes also developed in a concentration-dependent manner but had low intensity. Statistically significant activity was detected in concentrations of $10^{-5}$ and $10^{-4} \mathrm{M}$ only where the percentages of $\mathrm{C}_{12}$-HSL-treated TB(+) cells were $10.6 \pm 0.51 \%$ and $14.8 \pm 0.91 \%(p \leq 0.05)$, respectively, and the percentages of $\mathrm{C}_{12}$-AR-treated cells were $9.8 \pm 0.55 \%$ and 10.9 $\pm 0.61 \%$ ( $p \leq 0.05)$, respectively. The differences in monocyte viability at the lowest $\mathrm{C}_{12}$-HSL and $\mathrm{C}_{12}$-AR concentrations were non-significant compared to controls: 2.2 $\pm 0.13 \% \mathrm{~TB}(+)$ cells.

It is important to note that distinct forms of cell death cannot be distinguished by the trypan blue exclusion assay. This necessitates using specific methods for the detection of apoptotic and necrotic markers in $\mathrm{C}_{12}$-HSL- and $\mathrm{C}_{12}$-ARtreated cells.

\section{Expression of apoptotic markers in $\mathrm{C}_{12}$-HSL- and $\mathrm{C}_{12}$-AR-treated cells}

Granulocytes and monocytes were treated with or without $\mathrm{C}_{12}$-HSL or $\mathrm{C}_{12}$-AR for 1 and $4 \mathrm{~h}$. Cell lysates were collected and examined for caspase- 3 activity, and the level of histone-associated DNA fragments were compared to the non-treated controls (Table 1 ). $\mathrm{C}_{12}$ - $\mathrm{HSL}$, but not $\mathrm{C}_{12}$-AR, induced apoptosis in a concentration- and time-dependent manner, and the expressiveness of this effect was greater in granulocyte than monocyte cell lines.

We observed that granulocytes treated with $\mathrm{C}_{12}$ - $\mathrm{HSL}$ had more caspase- 3 activity; $10^{-6} \mathrm{M}$ of this compound was enough, and induction of apoptosis started within $1 \mathrm{~h}$. As shown in Fig. 2A, treatment of granulocytes with $\mathrm{C}_{12}$-HSL in concentrations of $10^{-6}, 10^{-5}$, and $10^{-4} \mathrm{M}$ for $1 \mathrm{~h}$ resulted in a dose-dependent increase in caspase- 3 activity to 8.60 $\pm 0.36,27.26 \pm 5.34$ and $101.27 \pm 10.34 \mathrm{ng} / \mathrm{ml}$, respectively. A 4-h treatment led to a 4-12-fold increase in caspase-3 activity becoming extremely high (110.35 $\pm 6.38-115.35$ $\pm 6.70 \mathrm{ng} / \mathrm{ml} ; p \leq 0.001)$ in the cell lysates. The monocyte line was not very sensitive, requiring $\mathrm{C}_{12}$-HSL concentrations of $10^{-5}$ and $10^{-4} \mathrm{M}$ to increase caspase- 3 activity only to $6.95 \pm 0.39$ and $10.25 \pm 0.58 \mathrm{ng} / \mathrm{ml}$ after a $1-\mathrm{h}$ treatment ( $p \leq 0.01$ ), and to $9.05 \pm 0.53$ and $12.05 \pm 0.75 \mathrm{ng} / \mathrm{ml}$ after 
Table 1. Effects of $\mathrm{C}_{12}$-HSL and $\mathrm{C}_{12}$-AR on granulocyte $(\mathrm{G})$ and monocyte $(\mathrm{M})$ viability markers after incubation for $1 \mathrm{~h}$

\begin{tabular}{|c|c|c|c|c|c|c|c|c|c|}
\hline \multirow[t]{2}{*}{$\begin{array}{l}\text { Type of } \\
\text { SMOMs }\end{array}$} & \multirow[t]{2}{*}{ Concentration, $\mathrm{M}$} & \multicolumn{2}{|c|}{$\begin{array}{c}\mathrm{TB}(+) \\
\text { dead cells, \% }\end{array}$} & \multicolumn{2}{|c|}{$\begin{array}{c}\text { Concentration } \\
\text { of active } \\
\text { caspase-3, nM }\end{array}$} & \multicolumn{2}{|c|}{$\begin{array}{l}\text { Enrichment factor, } \\
\qquad \mathbf{A}_{405}\end{array}$} & \multicolumn{2}{|c|}{ LDH activity, EA } \\
\hline & & $\mathbf{G}$ & $\mathbf{M}$ & $\mathbf{G}$ & $\mathbf{M}$ & $\mathbf{G}$ & $\mathbf{M}$ & G & $\mathbf{M}$ \\
\hline \multirow[t]{4}{*}{$\mathrm{C}_{12}$-HSL } & $10^{-7}$ & $\begin{array}{c}5.00 \\
(0.30)\end{array}$ & $\begin{array}{c}6.20 \\
(0.39)\end{array}$ & $\begin{array}{c}0.09 \\
(0.01)\end{array}$ & $\begin{array}{c}1.03 \\
(0.06)\end{array}$ & $\begin{array}{c}0.87 \\
(0.04)\end{array}$ & $\begin{array}{l}1.05 \\
(0.06)\end{array}$ & $\begin{array}{l}712.97 \\
(37.07)\end{array}$ & $\begin{array}{l}811.46 \\
(47.06)\end{array}$ \\
\hline & $10^{-6}$ & $\begin{array}{c}34.00^{* *} \\
(1.84)\end{array}$ & $\begin{array}{l}8.00 \\
(0.45)\end{array}$ & $\begin{array}{l}8.60 * * \\
(0.36)\end{array}$ & $\begin{array}{c}1.04 \\
(0.06)\end{array}$ & $\begin{array}{c}1.40 \\
(0.09)\end{array}$ & $\begin{array}{c}1.07 \\
(0.05)\end{array}$ & $\begin{array}{l}717.24 \\
(32.28)\end{array}$ & $\begin{array}{l}811.46 \\
(46.25)\end{array}$ \\
\hline & $10^{-5}$ & $\begin{array}{c}92.10^{* * * *} \\
(4.88)\end{array}$ & $\begin{array}{l}10.60 * \\
(0.51)\end{array}$ & $\begin{array}{c}27.26^{* *} \\
(5.34)\end{array}$ & $\begin{array}{l}6.95^{* *} \\
(0.39)\end{array}$ & $\begin{array}{l}2.43^{*} \\
(0.13)\end{array}$ & $\begin{array}{c}1.36 \\
(0.11)\end{array}$ & $\begin{array}{l}713.38 \\
(39.95)\end{array}$ & $\begin{array}{l}818.27 \\
(45.00)\end{array}$ \\
\hline & $10^{-4}$ & $\begin{array}{c}96.13 * * * \\
(4.99)\end{array}$ & $\begin{array}{l}14.80^{*} \\
(0.91)\end{array}$ & $\begin{array}{c}101.27 * * * \\
(10.34)\end{array}$ & $\begin{array}{c}10.25^{* *} \\
(0.58)\end{array}$ & $\begin{array}{l}7.03 * * \\
(0.42)\end{array}$ & $\begin{array}{l}1.62 * \\
(0.09)\end{array}$ & $\begin{array}{l}726.59 \\
(36.33)\end{array}$ & $\begin{array}{l}830.95 \\
(44.04)\end{array}$ \\
\hline \multirow[t]{4}{*}{$\mathrm{C}_{12}$-AR } & $10^{-7}$ & $\begin{array}{c}6.70 \\
(0.41)\end{array}$ & $\begin{array}{c}0.01 \\
(0.001)\end{array}$ & $\begin{array}{c}0.13 \\
(0.01)\end{array}$ & $\begin{array}{c}0.77 \\
(0.05)\end{array}$ & $\begin{array}{c}1.05 \\
(0.06)\end{array}$ & $\begin{array}{c}0.92 \\
(0.05)\end{array}$ & $\begin{array}{l}694.36 \\
(37.00)\end{array}$ & $\begin{array}{l}787.24 \\
(43.74)\end{array}$ \\
\hline & $10^{-6}$ & $\begin{array}{c}8.50 \\
(0.46)\end{array}$ & $\begin{array}{c}6.80 \\
(0.42)\end{array}$ & $\begin{array}{c}0.09 \\
(0.01)\end{array}$ & $\begin{array}{c}0.79 \\
(0.04)\end{array}$ & $\begin{array}{c}0.98 \\
(0.05)\end{array}$ & $\begin{array}{c}1.01 \\
(0.05)\end{array}$ & $\begin{array}{l}880.59^{*} \\
(46.67)\end{array}$ & $\begin{array}{l}799.86 \\
(36.79)\end{array}$ \\
\hline & $10^{-5}$ & $\begin{array}{c}68.60^{* *} \\
(3.49)\end{array}$ & $\begin{array}{c}9.80 \\
(0.55)\end{array}$ & $\begin{array}{c}0.13 \\
(0.01)\end{array}$ & $\begin{array}{c}0.85 \\
(0.06)\end{array}$ & $\begin{array}{c}1.00 \\
(0.06)\end{array}$ & $\begin{array}{c}0.84 \\
(0.05)\end{array}$ & $\begin{array}{c}1041.29^{* *} \\
(62.48)\end{array}$ & $\begin{array}{l}944.68^{*} \\
(57.63)\end{array}$ \\
\hline & $10^{-4}$ & $\begin{array}{c}95.90^{* * * *} \\
(4.98)\end{array}$ & $\begin{array}{l}10.90^{*} \\
(0.61)\end{array}$ & $\begin{array}{c}0.16 \\
(0.02)\end{array}$ & $\begin{array}{c}0.89 \\
(0.06)\end{array}$ & $\begin{array}{c}1.04 \\
(0.06)\end{array}$ & $\begin{array}{c}0.86 \\
(0.04)\end{array}$ & $\begin{array}{c}1205.16^{* *} \\
(65.08)\end{array}$ & $\begin{array}{l}959.83^{*} \\
(52.79)\end{array}$ \\
\hline Control & 0 & $\begin{array}{c}1.40 \\
(0.80)\end{array}$ & $\begin{array}{c}2.20 \\
(0.13)\end{array}$ & $\begin{array}{c}0.12 \\
(0.01)\end{array}$ & $\begin{array}{c}1.18 \\
(0.12)\end{array}$ & $\begin{array}{l}1.00 \\
(0.10)\end{array}$ & $\begin{array}{c}1.00 \\
(0.09)\end{array}$ & $\begin{array}{l}701.87 \\
(35.34)\end{array}$ & $\begin{array}{l}749.73 \\
(41.31)\end{array}$ \\
\hline
\end{tabular}

Data in triplicate on three different samples ( \pm standard errors)

$* p \leq 0.05 ; * * p \leq 0.01 ; * * * p \leq 0.001$ compared with the non-treated cells
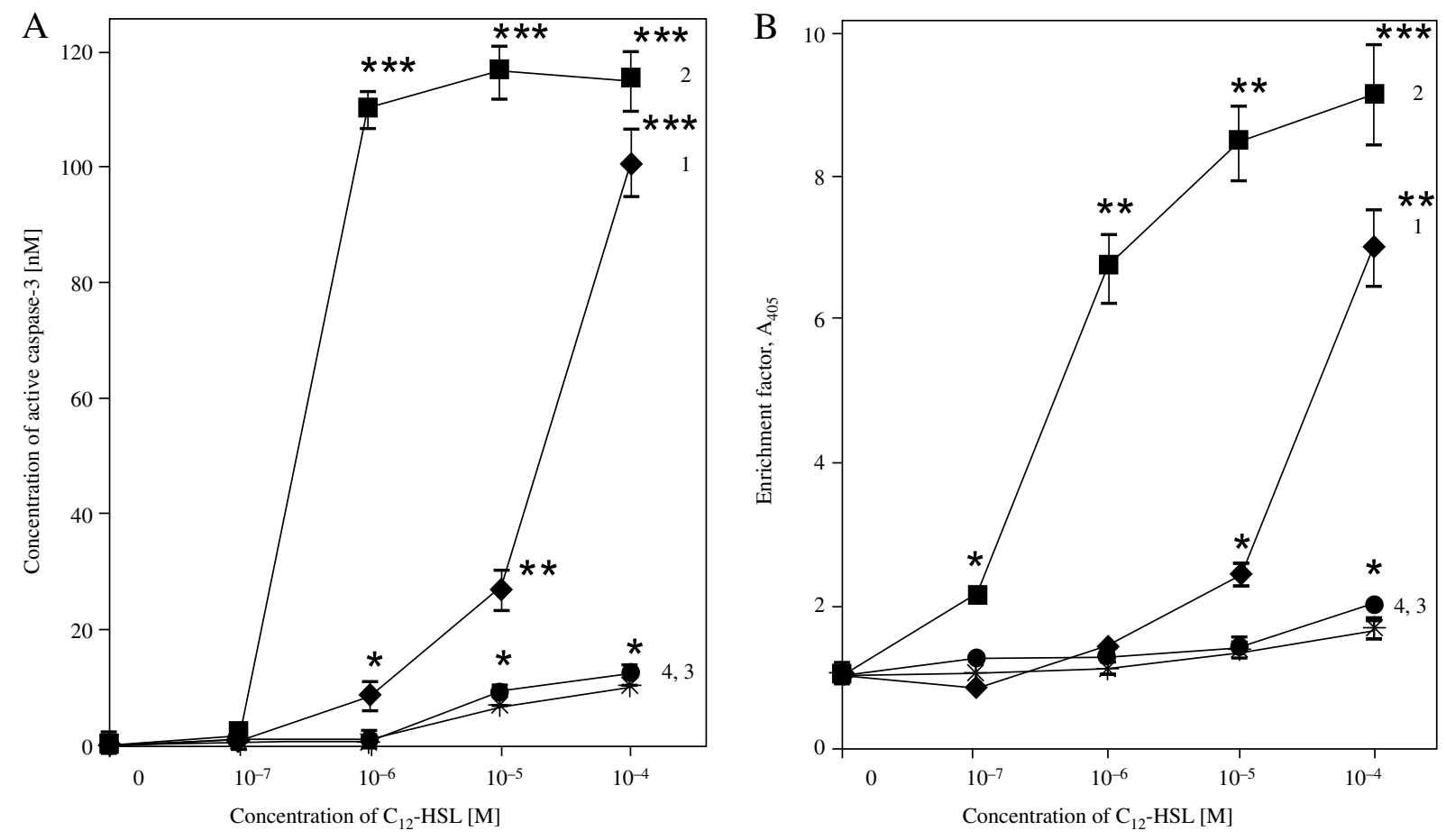

Fig. 2. Changes in apoptotic markers: caspase-3 activity (A) and level of histone-associated DNA fragments (B) after 1- and 4 h-incubations of granulocytes $(1,2)$ and monocytes $(3,4)$ with different $\mathrm{C}_{12}$-HSL concentrations. $* P \leq 0.05 ; * * P \leq 0.01$; $* * * P \leq 0.001$ compared with the nontreated cells 
a 4-h treatment $(p \leq 0.01)$, respectively. In the same assay, $\mathrm{C}_{12}$-AR did not show statistically significant activity.

Another hallmark of apoptosis is double-stranded, internucleosomal cleavage of DNA into regularly sized fragments. As shown in Fig. 2B, measurement of histone-associated mono- and oligonucleosome DNA fragments in sandwich-enzyme immunoassays indicated that treatment of granulocytes with $\mathrm{C}_{12}$-HSL led to DNA cleavage within $1 \mathrm{~h}$. A statistically significant enrichment factor (EF) value resulted from concentrations of $10^{-5}$ and $10^{-4} \mathrm{M}: 2.43 \pm 0.12$ and $7.03 \pm 0.42(p \leq 0.01)$, respectively. Treatment of granulocytes for $4 \mathrm{~h}$ resulted in more intensive DNA fragmentation with $\mathrm{EF}$ values from $6.74 \pm 0.35$ to $9.16 \pm 0.53$ ( $p \leq 0.01$ ), and $10^{-6} \mathrm{M} \mathrm{C}_{12}$-HSL was enough to induce apoptotic cell death. We observed similar tendencies when monocytes were treated with $\mathrm{C}_{12}$-HSL, but in this cell line there was less DNA fragmentation.

Together, these results indicate that treatment of granulocytes and monocytes with $\mathrm{C}_{12}$-HSL led to their apoptotic demise correlated with an effect on cell viability as determined using the Trypan blue dye exclusion method. However, these assays were ineffective in revealing $\mathrm{C}_{12}$ AR cytotoxic mechanisms other than apoptosis.

\section{Lactate dehydrogenase release from $\mathrm{C}_{12}$-HSL- and $\mathrm{C}_{12}$-AR-treated cells}

To explore the necrotic mechanism of cell death, we examined lactate dehydrogenase (LDH) release from gran-

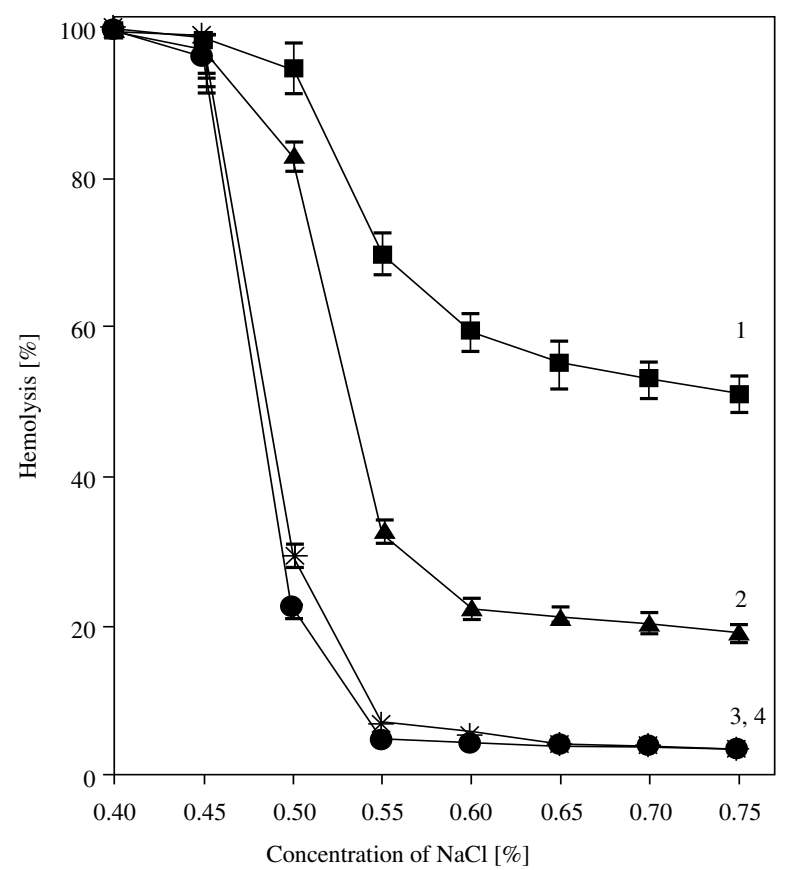

Fig. 3. Osmotic stability curves of erythrocytes treated with $\mathrm{C}_{12^{-}}$AR in concentrations of $10^{-4} \mathrm{M}(1), 5 \times 10^{-5} \mathrm{M}(2)$, $2.5 \times 10^{-5} \mathrm{M}$ (3), and control (4), used for half-transition point $\left(\mathrm{X}_{50}\right)$ calculation ulocytes and monocytes treated with or without $\mathrm{C}_{12}$-HSL or $\mathrm{C}_{12}$-AR. This enzyme is normally in the cytoplasm of eukaryotic cells, and its release into the culture medium strongly correlates with cell lysis [18].

Differences in LDH release between $\mathrm{C}_{12}$-HSL treated for $1 \mathrm{~h}$ and control cells were not apparent (Table 1). Detectable LDH activity appeared after $4 \mathrm{~h}$ of treatment only, probably as a secondary lysis of apoptotic cells (data not shown). In contrast, a significant increase in enzyme activity was demonstrated in cell supernatants treated with $\mathrm{C}_{12}$-AR for $1 \mathrm{~h}$, which is indicative of fast cell lysis. $\mathrm{LDH}$ release following treatment with $\mathrm{C}_{12}$-AR was slightly higher in granulocytes $(880.59 \pm 46.67,1041.29 \pm 62.48$, and $1205 \pm 65.08 ; p \leq 0.01)$ than in monocytes $(944.68 \pm 57.63$ and $959.83 \pm 52.79 ; p \leq 0.05)$, in which high concentrations of this compound were needed.

Taken together, these data suggest that $\mathrm{C}_{12}$-AR induces primary necrosis of granulocytes and monocytes, but $\mathrm{C}_{12^{-}}$ HSL contributes to their secondary necrosis as a result of apoptotic cell death.

\section{$\mathrm{C}_{12}$-HSL and $\mathrm{C}_{12}$-AR influence on membrane stability}

The fast cell lysis by $\mathrm{C}_{12}$-AR, but not $\mathrm{C}_{12}$-HSL, prompted us to examine the influence of these compounds on cell membrane stability. To this end, a hypotonic lysis of erythrocytes pre-incubated with $\mathrm{C}_{12}$ - $\mathrm{HSL}$ and $\mathrm{C}_{12}$-AR dilutions at $37^{\circ} \mathrm{C}$ for $1 \mathrm{~h}$ was examined in different $\mathrm{NaCl}$ concentrations.

The study revealed no differences between $\mathrm{C}_{12}$-HSL treated and control erythrocytes (data not shown). This behaviour would not be considered important in the membrane-disrupting mechanism of $\mathrm{C}_{12}$-HSL cytotoxicity. In contrast, the behaviour of erythrocytes treated with $\mathrm{C}_{12}$-AR shown in Fig. 3 can be estimated as membrane destabilization. The differences between the sigmoid osmotic stability curves and values of the half-transition point of the hypotonic hemolysis $\left(\mathrm{X}_{50}\right)$ were significant for cells promoted by $\mathrm{C}_{12}$-AR at concentrations above $5 \times 10^{-5} \mathrm{M}$. The control $\mathrm{X}_{50}$ value was $0.46 \pm 0.03 \mathrm{~g} / \mathrm{dl} \mathrm{NaCl}$, and when erythrocytes were pre-incubated with $5 \times 10^{-5} \mathrm{M}$ of $\mathrm{C}_{12}$-AR this increased to $0.54 \pm 0.04 \mathrm{~g} / \mathrm{dl} \mathrm{NaCl}(p \leq 0.001)$; for $10^{-4} \mathrm{M}$ $\mathrm{C}_{12}$-AR-treated cells, the value increased to $0.78 \pm 0.04 \mathrm{~g} / \mathrm{dl}$ $\mathrm{NaCl}(p \leq 0.01)$. This suggests that $\mathrm{C}_{12}$-AR induced higher membrane permeability and affected the membrane stability, thus, operating in a similar fashion as other long-chain resorcinolic lipids [19, 20].

These data suggest that a significant part of $\mathrm{C}_{12}$-AR, but not the $\mathrm{C}_{12}$-HSL cytotoxic effect, is related to an interaction with membranes, and this interaction can lead to fast cell lysis (necrosis) without an induction of apoptosis.

\section{Discussion}

Cell death caused by small molecules originating from microbes (SMOMs) is one of the most extreme develop- 
ments in the field of inter-kingdom relationships [1, 2]. We have made two conclusions by studying the cytotoxic mechanisms of two structurally close SMOMs: $N$-dodecanoylL-homoserine lactone and 5- $N$-dodecyl resorcinol. First, both compounds in micromolar concentrations showed significant dose-dependent cytotoxicity in granulocytes but not in monocytes. Second, these molecules use different mechanisms to impinge on the cell death pathway.

The present data demonstrate that $\mathrm{C}_{12}$-HSL specifically induces apoptosis in granulocytes and monocytes. Recently, the pro-apoptotic activity has been reported for another HSL, a 3-oxo- $N$-dodecanoyl-L-homoserine lactone (3-oxo- $\mathrm{C}_{12}$-HSL) originating from Pseudomonas aeruginosa [14]. However, any changes in cell viability caused by other HSLs were still not observed. Our data for the first time demonstrate the specific ability, distinct from 3-oxo$\mathrm{C}_{12}$-HSL homoserine lactone, of $\mathrm{C}_{12}$-HSL to induce cell death by apoptosis. On the other hand, we confirm that HSLs' fine structure, in particular the sufficient length of side chains, is very important for the ability of these molecules to express cytotoxic activity and induce apoptosis.

In addition to the known toxic and regulatory $\mathrm{C}_{12}$-HSL functions, such as alteration of human cell cycling and metabolism, activation of NF- $\mathrm{KB}$ in macrophages [6] or increasing the expression of TNF- $\alpha$, interleukin- $1 \beta$, and interleukin- 8 [5], the present data testify to the expressed immunomodulatory activity of this molecule. First and most obvious, because apoptosis is a critical event for immunological and inflammatory processes, its dysregulation may greatly favour the survival of HSL-producing bacteria in their hosts.

Despite the effective induction of apoptosis previously observed after treatment with some resorcinolic lipids [15, 16 , we have not observed this activity for $C_{12}-A R$. In contrast, this molecule induced fast cytolytic effects shown by the release of cytoplasmic lactate dehydrogenase, and presumably was defined by cellular membrane destabilisation. Therefore, the ability of resorcinolic lipids to incorporate into the phospholipid bilayer [16], to induce higher membrane permeability, and to induce cell lysis [19] proves to be true. In accordance with the previously shown ability of some ARs to regulate bacteriolytic enzyme activity [20], and to block antigen-antibody interactions [21], the data gathered strongly suggest the involvement of this molecule in the regulation of the immune response.

In summary, the present data demonstrate that $\mathrm{C}_{12}$-HSL and $\mathrm{C}_{12}$-AR can eliminate key defence cells, such as monocytes and especially granulocytes, which would otherwise participate in the destruction of pathogenic bacteria. These results reinforce the SMOMs bifunctionality concept that such bacterial molecules not only regulate bacterial-bacterial interactions but also break immune defences as a new and important mechanism of host evasion.

The authors declare no conflict of interests.
This work was supported by grants from the Russian Foundation of Basic Research (RFBR No. 11-04-12057), and the Orenburg State University Research Program (No. 4.2312.2011).

\section{References}

1. Hughes DT, Sperandio V (2008): Inter-kingdom signalling: communication between bacteria and their hosts. Nat Rev Microbiol 6: 111-120.

2. De Kievit TR, Iglewski BH (2000): Bacterial quorum sensing in pathogenic relationships. Infect Immun 68: 4839-4849.

3. Kozubek A, Tyman JHP (1999): Resorcinolic lipids, the natural non-isoprenoid phenolic amphiphiles and their biological activity. Chem Rev 99: 1-25.

4. El-Registan GI, Mulyukin AL, Nikolaev YuA, et al. (2006): Adaptogenic functions of extracellular autoregulators of microorganisms. Microbiologia 75: 380-389.

5. Miyairi S, Tateda K, Fuse ET, et al. (2006): Immunization with 3-oxododecanoyl-1-homoserine lactone-protein conjugate protects mice from lethal Pseudomonas aeruginosa lung infection. J Med Microbiol 55: 1381-1387.

6. Ross AB (2012): Present status and perspectives on the use of alkylresorcinols as biomarkers of wholegrain wheat and rye intake. J Nut Met 12: 1-12.

7. Ritchie AJ, Jansson A, Stallberg J, et al. (2005): The Pseudomonas aeruginosa quorum-sensing molecule N-3-(oxododecanoyl)-L-homoserine lactone inhibits T-cell differentiation and cytokine production by a mechanism involving an early step in T-cell activation. Infect Immun 73: 1648-1655.

8. Gomi K, Kikuchi T, Tokue Y, et al. (2006): Mouse and human cell activation by N-dodecanoyl-DL-homoserinelactone, a Chromobacterium violaceum autoinducer. Infect Immun 74: 7029-7031.

9. Kristiansen S, Bjarnsholt T, Adeltoft D, et al. (2008): The Pseudomonas aeruginosa autoinducer dodecanoyl-homoserine lactone inhibits the putrescine synthesis in human cells. APMIS 116: 361-371.

10. Stasiuk M, Kozubek A (2010): Biological activity of phenolic lipids. Cell Mol Life Sci 67: 841-860.

11. Vaux DL, Korsmeyer SJ (1999): Cell death in development. Cell 96: 245-254.

12. Hengartner MO (2000): The biochemistry of apoptosis. Nature 407: 770-776.

13. Tateda K, Ishii Y, Horikawa M, et al. (2003): The Pseudomonas aeruginosa autoinducer $\mathrm{N}$-3-oxododecanoyl homoserine lactone accelerates apoptosis in macrophages and neutrophils. Infect Immun 71: 5785-5793.

14. Jacobi CA, Schiffner F, Henkel M, et al. (2009): Effects of bacterial $\mathrm{N}$-acylhomoserine lactones on human Jurkat $\mathrm{T}$ lymphocytes-OdDHL induces apoptosis via the mitochondrial pathway. Int J Med Microbiol 299: 509-519.

15. Gasiorowski K, Brokos B, Kulma A, et al. (2001): Impact of four antimutagens on apoptosis in genotoxically damaged lymphocytes in vitro. Cell Mol Biol Lett 6: 649-675.

16. Buonanno F, Quassinti L, Bramucci M, et al. (2008): The protozoan toxin climacostol inhibits growth and induces apoptosis of human tumor cell lines. Chem Biol Interact 176: 151-164.

17. Lemos GS, Márquez-Bernardes LF, Arvelos LR, et al. (2011): Influence of glucose concentration on the membrane stability of human erythrocytes. Cell Biochem Biophys 61: 531-537. 
18. Rydell-Tormanen K, Uller L, Erjefalt JS (2006): Direct evidence of secondary necrosis of neutrophils during intense lung inflammation. Eur Respir J 28: 268-274.

19. Acevedo HR, Rojas MD, Arceo SD, et al. (2006): Effect of 6-nonadecyl salicylic acid and its methyl ester on the induction of micronuclei in polychromatic erythrocytes in mouse peripheral blood. Mutat Res 609: 43-46.

20. Petrovskii AS, Loiko NG, Nikolaev YuA, et al. (2009): Regulation of the functional activity of lysozyme by alkylhydroxybenzenes. Microbiology 78: 144-153.

21. Deryabin DG, Mikhailenko NA, El-Registan GI (2009): The effect of alkylhydroxybenzenes on the antigen-binding capacity of antibodies. Microbiology 78: 569-574. 